Except for a couple of summary chapters, Jonas's account ends just after the Second World War. It is thus confined to the 'circuit riding' period of Rockefeller philanthropy, before the modern peerreview system emerged. Like the frontier Methodist preachers riding their circuits, Rockefeller's philanthropoids travelled incessantly in search of worthy recipients. Officials at the top of the Rockefeller balance, they seem to have used reasonably. Jonas (a staff writer for The New Yorker) does not attempt to tell the whole story. There is little on the Rockefeller hierarchy had enormous power which, on

Institute itself, or on the endowment of the schools of public health, and rather too much on Florey and penicillin. But he is good on the gradual shift from bricks and mortar philanthropy to more support for individual scientists, on the development of informal networks of advisors, and on the personal contributions of key philanthropoids. Jonas gives us an apposite portrait of modern science in the making, but still not fully made.

W.F. Bynum is at the Wellcome Institute for the History of Medicine, 183 Euston Road, London NW1 2BP, UK

\section{Mad for money}

\section{Daniel S. Greenberg}

Ungulded Missiles: How America Buys Its Weapons. By Fen Hampson. W.W. Norton: 1989. Pp.348. \$19.95.

THE military establishment in the United States is often depicted as a rogue enterprise that thrives against the will of the body politic. President Dwight Eisenhower suggested that conception in his valedictory warning against the "militaryindustrial complex". Numerous works, academic and journalistic, have taken up the theme, exposing the wily collusions of the Pentagon and its political and industrial collaborators.

Hampson, a professor of international relations at Carleton University, Ottawa, carries on the tradition by applying economic analysis and game theory to a halfdozen of the military's grandest research and procurement extravaganzas - the B-1 bomber, the Trident missile system, the MX missile, the air-launched cruise missile, the Strategic Defense Initiative and the Abrams tank (covered in a chapter by a colleague, N. Swales). Referring to and quoting heavily from numerous works by others, Hampson observes that these systems have survived years - even decades - of political opposition, premature obsolescence and cost increases vastly beyond the original estimates. Except in rare instances, weapons systems that have passed the research stage have proven to be invulnerable to termination, whether for political or technical reasons. Why?

The answer, says Hampson, is that the military services compete for budgets up to a point, but their rivalries are "marked by 'competitive cooperative' behavior akin to that noted by economists in oligopolistic settings and by game theorists in iterated or repetitive games" (p. 301). Specifically, the sacred systems of each service - the Navy's carriers, the Army's tanks, and the Air Force's missiles and manned aircraft - are out of bounds for

serious challenge by the others.

So much for the collusion of the military services. What of their presumed political masters in Congress? "Congress almost never addresses the fundamental question 'Should we fund this program?' Rather, the question is 'How much?' Once we understand the logic of this process it becomes easier to see why weapon programs rarely die at the hands of Congress" (p. 47). One reason they don't die is the high 'pork' value of defence spending, as typified by the distribution of B-1 bomber subcontracts to 48 states. When a challenge to the programme's budget developed, the Air Force and its main contractor, Rockwell, roamed Capitol
Hill, with lists of every contract crossreferenced by state, town and Congressman.

And the White House? During eight years of Reagan, it never met a major weapons system it didn't like. But even before Reagan, the champions of big weapons systems rarely encountered effective political opposition. Jimmy Carter, for example, banned the start of production on the B-1. But, as Hampson reports, Carter later lamented that "the enormous B-1 lobbying octopus was still alive and writhing. It would live to fight again after I left the White House" (p.163).

Again and again, the weapons champions have overcome political resistance and even technological good sense to field their systems. Mobility, as a safeguard against a sudden Soviet strike, was a

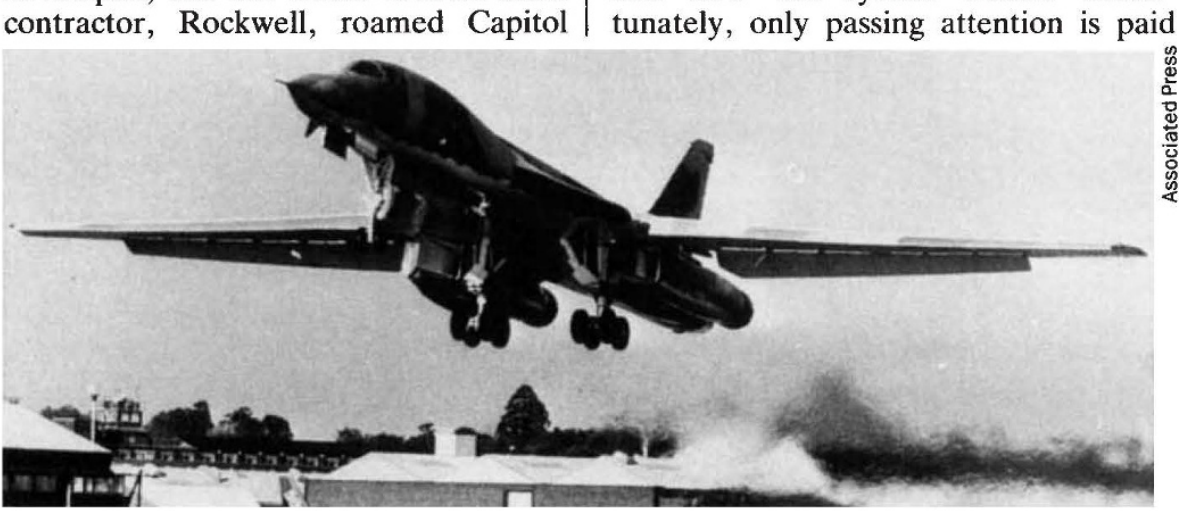

Pork on the wing - the US Air Force B-1 bomber at Farnborough, Britain in 1982.

major rationale for the $\mathrm{MX}$, a missile system that survived 13 years of difficult gestation. Advocates of arms control feared it as a provocative first-strike weapon. And no satisfactory means of moving it about was ever devised. As a last resort, the MX was based in stationary silos originally built for Minuteman missiles. Hampson notes that Carter tolerated the MX's survival "to appease Congressional hardliners who worried that arms control would lull the United States into a false sense of security". $\mathrm{He}$ adds that "Worries about ICBM [intercontinental ballistic missile] vulnerability were all but swept under the rug of political expediency" (p. 143)

From the case studies, Hampson concludes that the military establishment, industrialists and politicians all view the defence budget as a bountiful resource that can accommodate all claimants if none is too greedy. The bargaining process, he explains, "assures rewards or payoffs to all parties from cooperative behavior. A program will therefore not get all of the funds and resources its sponsors want, but, by the same token, it will rarely be killed" (p. 303).

By combining the rogue thesis with game theory and economic analysis, Hampson thus provides useful insights into how the system works. Unfortunately, only passing attention is paid

to a more important and little-explored issue: why is the system tolerated, when, demonstrably, its extravagance and technological obtuseness detract from national security and result in the squandering of resources? What is the fertile ground on which this venerable militarypolitical-industrial complex has thrived for 40 years?

The answer, of course, is the Soviet threat, surely real, but repeatedly manipulated and misrepresented by the 'weaponeers' to undermine opposition and to create a climate of opinion favourable to any weapons system - no matter how foolhardy and expensive. Hampson observes that "Little doubt exists that intelligence and threat assessments are highly politicized assets in weapons programs" (p. 287). He notes, too, that "As the level of resources required by a 

the external threat more vividly and characterize it in terms of greater rather than less certainty" (p. 286).

There's paydirt in those themes - far more than in the exhausted thesis of interservice and political backscratching as the explanation for the success of the weapons economy. For decades, US political consciousness has been steeped in fears of aggressive Soviet military intentions. Reagan drew applause from across the political spectrum when he decreed that defence spending must grow while all other government spending would be reduced. During his two terms in office, the military share of federal research spending rose from 50 to 70 per cent of the total - there were virtually no dissenting voices. In electoral politics, an unrebutted allegation of weakness on defence is almost invariably fatal. Just before taking office, the new Secretary of Defense, Dick Cheney, warned that it would be "a grave program grows, its sponsors may project

mistake" to cut defence spending.

Hampson concludes that the "weapons acquisition and budgetary process must be restructured so that it becomes more of a zero-sum game" (p. 279). Towards this goal, he recommends stricter Congressional oversight, clearer budget presentations, and various other tinkerings with the political and organizational underpinnings of the system. All have been suggested before. At one time or another, some have been put into practice, only to fail in their intended objective of rationalizing the design and purchase of weapons. That failure does not arise from defective bureaucratic arrangements. Rather, it comes from a distorted world view that insists that a menace is at the gates and nothing is too costly, or too mad, in the quest for security.

Daniel S. Greenberg, 3736 Kanawha Street NW, Washington, DC 20015, USA, is editor and publisher of Science \& Government Report.

\section{Standard bearers} Philip Gummett

The Evaluation of Sclentific Research. Ciba Foundation, chairman Sir David Phillips. Wiley: 1989. Pp.284. £32.50, $\$ 57.95$.

ONE of the first papers that I submitted for publication was returned by the editor, saying that he would take it if I removed a section that he judged to be of no interest. Being keen to get into print, I complied. Later, I decided that the excised section was still worth publishing. I sent it, duly smartened up, to another editor, who accepted it. At a stroke my productivity, as measured by publications, had apparently shot up.

Such an experience induces a healthy scepticism about performance indicators for research. Current talk in academic common rooms about 'citation rings' and 'smallest publishable units' only adds to the scepticism. Yet performance indicators, and evaluations of scientific research based upon them, are unquestionably here to stay. We have to learn to live with them, which means learning what can sensibly be used, for what purposes, and within what limits.

The Ciba Foundation therefore did valuable service by holding, in June 1988, an international conference of experts in evaluation to take stock of the state of the art. This book is the final product of the meeting. It is made up of 14 short papers, an introduction and summing up by Sir David Phillips, chairman of the UK Advisory Board for the Research Councils, and the text of the discussions. What emerges is a variegated blend of techniques, methodological issues and case studies. Clearly, evaluations now come in all shapes and sizes. Some are concerned with evaluating national performance in science and technology; some with institutions, such as the British technological universities; some with programmes, such as the Alvey fifth-generation computer programme; and some with research groups. Others explore the operations of peer review systems; the impact of different modes of research funding; and the links between science and technology. One paper even attempts to evaluate the evaluators - surely a growth subject.

Underlying the whole discussion is a tension between those who are confident of the value of quantitative evaluative methods, hedged with caveats about the need for sensitive and skilled handling, and those who express concern that what can be quantified are only epiphenomena. Thus, although one contributor dismisses the long-standing debates on the meaning of citations as "rather arid" (p.13), others argue that indicators and evaluative techniques can only be worthwhile within the framework of a clearer understanding of the dynamics of science and technology, and their interaction with the economy.

To some extent, as is pointed out in the book, this is a debate between pragmatic science policy analysts and more theoretically inclined historians and sociologists of science. But it would be wrong to 'sociologize' away the debate this easily. For example, the book contains ample evidence of disagreements among even the most pragmatic participants over the acceptability of various bibliometric procedures, even down to such questions as how to count multi-authored papers, or how to define fields of science. These are not purely technical questions; their reso- lution depends in part upon what one believes to be the importance of collaboration for the advance of science, or upon one's view of the relations between fields.

Indeed, disagreements over such points raise the question of what precisely is the evaluator's art. The contributors to this volume offer various answers. One sees himself as a guerilla rather than a regular soldier, though it is surely unusual for guerillas to be paid by the established government. Others discuss whether their role model is management consultancy, medicine, the law, designers of expert systems or writers of spy novels. The claim by one contributor, that those attending the conference were "a community of technicians in the business of evaluation", earned a sharp riposte from another participant who said that those present who felt themselves to be part of the scientific community were more concerned with understanding how science works, and what the scope might be for any kind of policy influence on the production of scientific knowledge (p.88).

Such differences of view also raise the issue of how professional standards are to be upheld among a group of analysts with growing influence in the corridors of power. There are disturbing references in the book to evaluators being sent back to "improve the picture" (p.28), and to the difficulties of maintaining integrity in the close relationship that, for a successful evaluation, exists between evaluator and customer. Statements about the importance of remaining outside political debate sit awkwardly against a long-established literature on the impossibility of scientific advisors acting apolitically. Most participants also seemed curiously unaware that, as one of their number pointed out (p.29), the activity of programme evaluation is not new, having been done on a large scale in social policy for 30 years, and that many of these issues have been addressed before.

One suggestion that emerged was for a code of ethics for evaluators to be laid down. Another was that evaluators should seek professional legitimation from within the field of science and technology studies, which could provide an intellectual critique of the meaning of indicators and techniques. Given the scale of commitment to evaluation of scientific research, these matters ought urgently to be addressed. As Sir David Phillips remarked, it may be that, like the proverbial drunk looking for a lost wallet, we are searching under a street lamp simply because that is where it is light - particularly the light provided by the Science Citation Index. Whether we are learning much about real scientific performance, however that may be defined, is a serious question that this book does much to air.

Philip Gummett is Head of the Department of Science and Technology Policy, University of Manchester, Manchester M13 9PL, UK. 